\title{
Отвъд думите: транс-езиковото номадство в романите на Ева Хофман и Александър Хемон
}

\author{
Корнелия СлАВОВА \\ Софийски университет „Св. Климент Охридски” \\ kornelias@abv.bg
}

Recibido: Mayo de 2013

Aceptado: Diciembre de 2013

\section{Резюме}

Статията разглежда два съвременни романа на Ева Хофман и Александър Хемон, писатели от славянски произход, които се установяват в Америка и пишат на английски. Като проследява ролята на транслингвизма, анализът разкрива как прехвърлянето на границите на езика е свързано с прехвърлянето на границите и ограниченията на мисълта, въображението и идентичността. В заключение се твърди, че двамата писатели развиват критично номадско съзнание, което ги прави способни да мислят и си представят света по различен начин.

Ключови думи: Ева Хофман, Александър Хемон, транслингвална литература, език

\section{Más allá de las palabras: Nomadismo translingüistico en las novelas de Eva Hoffman y Aleksandar Hemon}

\section{Resumen}

El artículo analiza dos novelas contemporáneas de Eva Hoffman y Alexandar Hemon - escritores de descendencia eslava que se instalan en América y escriben en inglés. Al estudiar el papel del translingüismo el análisis revela cómo trascender los límites del lenguaje conlleva trascender los límites y las limitaciones del pensamiento, la imaginación, y la construcción de la identidad. Se afirma que los dos escritores desarrollan una conciencia crítica nómada que se resiste a la fijeza y la unidad y les permite imaginar y pensar de otra manera.

Palabras clave: Eva Hoffman, Aleksandar Hemon, literatura de translingüismo, lenguaje

\section{Beyond Words: Translingual Nomadism in the Novels of Eva Hoffman and Aleksandar Hemon}

\begin{abstract}
The article discusses two contemporary novels by Eva Hoffman and Alexandar Hemon - writers of Slavic descent who settle in America and write in English. By tracing the role of translingualism, the analysis reveals how transcending the boundaries of language relates to transcending the limits and limitations of thought, imagination, and identity construction. It is argued that the two writers develop a critical nomadic consciousness that resists fixity and unity, enabling them to imagine and think otherwise.
\end{abstract}

Key words: Eva Hoffman, Aleksandar Hemon, translingual literature, language 
В съвременния глобален свят все повече писатели живеят извън границите на своите национални култури, както и творят на различен от родния си език. Настоящият текст се вглежда в транс-езиковото (транслингвалното) литературно въображение на Ева Хофман и Александър Хемон - двама съвременни автори от славянски произход, които не просто се движат между световете на Източна Европа и Америка, но и ги преоткриват и съизмерват един чрез друг. Подобно на своите създатели, героите на Хофман и Хемон тьрсят свобода и възможности в Америка: тя бяга от комунистическа Полша в края на петдесетте години на XX век, а той от разкъсаната от междуетнически войни Босна през 90-те години XX век. Съпоставката между техните автобиографични романи Изгубена в превода: живот на нов език (1989) и Човек от никъде: фантазиите на Пронек (2002) - написани на английски ${ }^{1}$ - поражда серия от интересни въпроси за транс-езиковите практики: как литературните текстове оживяват отвъд границите на нацията и на езика? Колко пропускливи са тези граници? В каква степен изоставянето на майчиния език е акт на самоунищожение или пък средство за самопретворяване?

Наративите на Хофман и Хемон извират от източната периферия на Европа и могат да се разглеждат по много начини: като литература на изгнанието или емигрантски разкази, като съвременни космополитни романи или като превод между култури и дори форма на самопревеждане. Настоящият текст обаче анализира двата романа през теоретичната рамка на литературния транслингвизъм (литературно явление, при което авторът създава творбите си на повече от един език или поне на един език, различен от майчиния), 2 защото и в двата случая езикът функционира като основна категория на (пре)сътворяване на авторовата идентичност - по-осезаема от всяка друга категория на човешкото различие, като например националност, религия, род/ пол, етническа или регионална принадлежност. Писането отвъд родния език и среда създава условия за изразяване на два гласа, нещо като двойна визия или съзнание. Това състояние е много продуктивно за сравнителен анализ, защото вторият/ чуждият език и култура променят познатите звуци, структури и понятия, докато родният език и култура от своя страна задвижват литературното въображение на писателя и го правят по-възприемчив към чуждото и непознатото. По този начин трансезиковото писане показва как прехвърлянето на границите на езика се свързва с прехвърлянето на границите и ограниченията на мисленето, на въображението и на идентичността на твореца. То илюстрира в каква степен родният език и култура са закодирани в нашите усещания и разбирания, как самият ни живот зависи от живата реч в нас. И не на последно място транслингвалните процеси насочват към въпросите на другостта: какво означава да си чужденец в собствената си родина, как изглежда „другият” като чужденец, както и представата за самия себе си като чужденец. Настоящият текст ще анализира тези три основни модела на чуждостта в романите на Хофман и Хемон именно през призмата на езика.

\footnotetext{
1 Двата романа не са превеждани на български език, затова преводите на всички цитати и препратки към тях са на автора на тази статия според английските издания HOFFMAN (1989) и HEMON (2002).

2 Тази дефиниция е почерпана от KELLMAN (2000).
} 
Славянската литература притежава богата традиция на изтькнати транслингвални писатели като Джозеф Конрад, Елиъс Канети, Владимир Набоков, Марина Цветаева, Милан Кундера, Том Стопард, Юлия Кръстева, Славенка Дракулич, Капка Касабова и много други. В повечето случаи чуждият/ вторият език служи като маска или средство за по-успешното им приобщаване в изгнание, но понякога транс-езиковото творчество се свързва със съзнателно експериментиране и само-обновление. Хофман и Хемон напускат родината си по различно време и причини, но и двамата не се асимилират в американската среда; вместо това те рисуват една доста сложна картина на собственото си трансформиране на нов глас/ език - в противовес на класическите европейски разкази за триумф в обетованата земя. За тях новоусвоеният (английски) език се превръща метафорично в мястото, чрез което навлизат и постепенно приемат чуждата култура, както и новата си същност.

Ева Хофман напуска Полша на тринадесет години през 1959 година, когато нарастващият антисемитизъм принуждава родителите ѝ (евреи, преживели Холокоста) да търсят спасение отвъд Атлантическия океан. Прекарала по-голяма част от живота си в Канада и САЩ, Хофман постепенно изоставя родния си език и заживява на английски, както подсказва самото заглавие на автобиографията ѝ „Изгубена в превода: живот на нов език”. Романът е разделен на три части: първата, озаглавена „Рай”, е вълнуващ спомен за детството ѝ в прекрасния Краков; втората, озаглавена „Изгнание”, описва трудното израстване сред „културната пустиня” (HOFFMAN 1989: 88) на Канада, докато третата част е по-зряло описание на живота ѝ в „Новия свят” (т.е. САЩ) - следването ѝ в Университета Райс в края на 60-те години, получаването на докторска степен по литература от Харвард, както и успешната ѝ кариера на литературен редактор. Самата структура на романа, която се движи от „рая” през „изгнаничеството” към „Новия свят”, преобръща традиционната траектория на имигрантската литература, където обикновено имигрантите вървят към бленувания рай .3

Разказът на Хофман обаче съвсем не е щастлива приказка: тя преживява драматично загубата и отсъствието на любимата Полша и полски език. С голяма доза скептицизъм и нюансираност Хофман описва своето транс-езиково превъплъщение на английски като мъчение. Напускането на Краков / Полша най-красивото място за Хофман - не бележи началото на нов живот, а по-скоро е „ськрушителен и ясен край”, който тя сравнява с „края на живота” и „края на света" (HOFFMAN 1989: 3). В момента, в който корабът потегля от Гдиня, Ева сякаш потьва в „някакво нереално място на другия край на света”, започва да се възприема като нереален човек - героиня от роман „извън пространството” и „извън времето” (НOFFMAN 1989: 9). Наративът на Хофман е изпълнен с носталгия по всичко, което е останало в Полша - едно силно чувство на тъга и копнеж, което авторката назовава с полската дума teşknota (HOFFMAN 1989: 4, $20,28,91,115,116)$ - сякаш английската лексика не е напълно адекватна да обхване и изрази емоциите й.

\footnotetext{
3 Например, в своята автобиография Обетованата земя (1912) Мери Антин описва бягството си от антисемитска Русия в края на XIX в. в Америка, като прегръща новата си родина и език с огромна любов.
} 
Чуждият език се оказва основна пречка за приспособяването на Хофман към Новия свят, но след години усилия той се превръща в средство да усети и приеме този свят. В началото, при самото установяването на семейството във Ванкувър, тя не харесва езика на децата от квартала, с които си играе - струва ѝ се агресивен „с твърдо звучене” и не „може да си представи как би пожелала да го говори" (HOFFMAN 1989:105). Първата английска фраза, която научава да разпознава в доста драматичен контекст, е всъщност подвикването на децата в двора на училището “Shut up, shuddup!” (HOFFMAN 1989: 104), което асоциира чуждия език с насилственото мълчание, а не с общуването. Сред многото неприятни и тежки моменти в Канада, които Хофман описва, най-травмиращо е нейното „второ кръщаване” - решението на учителката да англицизира името на сестра ѝ от „Алина” на „Елейн”, както и нейното собствено полско име „Еwa” на английското „Еva” (HOFFMAN 1989: 105). Този акт бележи началото на едно сериозно раздвояване на личността на съзряващата Хофман или, както тя я определя, „сеизмична промяна в психиката”. Ева се чувства не само чужденка в чужда земя, но и „чужденка на самата себе си” (HOFFMAN 1989: 105) - фраза, която отеква като ехо от психоаналитичната теория на Юлия Кръстева, друга транс-езикова писателка от български произход, която в книгата Чужденци на самите себе си анализира чуждото като „унищожаване на аза" (KRISTEVA 1991: 188), но и отваряне към нещо ново - усещането за собствената ни различност. ${ }^{4}$ Ева трудно намира правилните дума на английски, не знае жаргона на местните хора, речникът ѝ е ограничен; затова се чувства откъсната, изолирана и дори скучна - „фалшива фигура, в която е напъхана" (HOFFMAN 1989: 109).

Чуждият език не пасва на нейната вътрешна вселена; новите думи са просто знаци от страниците на книгите и учебниците - сякаш „означаващото е разделено насила от означаемото" - обяснява тя по-късно в семиотични термини на академичния английски език, който е овладяла в Харвард. За Хофмановата героиня родният език присъства в самите сетива и възприятия, затова с мъка споделя невъзможността си да назове на новия език вътрешните си преживявания: „Думите, които научавам, не се отнасят към нещата по същия начин, както на родния ми език” (HOFFMAN 1989: 106). Някои от думите са просто непреводими или нямат еквивалент на английски. Подобно на teşknota, Ева не може да намери в богатия английския речник любимата си полска дума, която повтаря като мантра „polot”-,дума, която съчетава значенията на устрем, вдъхновение и полет - спонтанност, малко безразсъдство, страст" (HOFFMAN 1989 : 71, 154, 159). Индиректно тя ни внушава, че езиковите системи не са просто заменими: полският език поражда някои мисли и емоции, които не може да изпита на друг език.

Непреводимостта на отделни думи или понятия кара героинята да осъзнае, че разминаването в смисъла, значенията и конотациите на думите е въпрос на непреводимостта или несъизмеримостта на самите култури, ценности и начин

\footnotetext{
4 Според Кръстева всички ставаме чужденци, щом осъзнаем своята другост: „Чужденецът/ другият е в мен, затова всички сме чужденци" (KRISTEVA 1991 :172).
} 
на живот, между които живее. Например, за Ева простичката дума „приятел” на полски означава „силно чувство на лоялност и привързаност, на ръба с любовта”, докато английското „friend” покрива „небрежно всякакви територии” (HOFFMAN 1989: 148); английското „river” звучи „студено, няма никаква аура, и не извиква никакви асоциации”, за разлика от полската дума за „река” (HOFFMAN 1989: 106); дори млякото не е „същата течност, макар и да се нарича със същото име” (HOFFMAN 1989: 106). Абстрактните категории също не отговарят на установените представи на съзряващата героиня: онова, което на полски е „нормално и странно” не съответства на английските разбирания за "normal and weird" (HOFFMAN 1989: 147, 172). По подобен начин думите или фразите „вулгарен”, „любезност”, „реклама”, „консуматорство”, “разговор”, “добро семейство" и много други са изпълнени с различен смисъл в двата езика. Но дали несъответствията са просто между различните реалности или между заложеното в тях преживяване? Години по-късно авторката обяснява тези разминавания като радикално накъсване между думата и нещото, към което препраща - „странна алхимия, която лишава света не само от неговите цветове, жилки, нюанси - от самото му съществуване”, т.е. тя осъзнава, че това e ,загубата на живата връзка” с родния език и Полша (HOFFMAN 1989: 107).

Още по-големи са несъответствията между думите, пакетирани в различните култури и идеологии на комунистическия Изток и капиталистическия Запад. Такъв е случаят с разбирането за „женственост”: в Полша женската сила се свързва със способността да накараш другите да правят неща за теб, т.е. „да бъдеш мързелива и глезена” (HOFFMAN 1989: 15) или да притежаваш „изискана кокетност", докато в американското разбиране за женска красота и здраве има елемент на „усилие - да тичаш, плуваш или ходиш на аеробика" (HOFFMAN 1989: 55). Ценностите и начинът на живот също не си кореспондират: от едната страна стои пуританската традиция на „работна етика, ред и подчиняване на реда”, а от другата, безкрайните социалистически игри „на надхитряване на Системата - една доста систематична система”, като полският скептицизъм спрямо всички системи превръща, според Ева, поляците в нация на „иронични наблюдатели и комарджии” (HOFFMAN 1989:15). Аналогично, през призмата на думите тя забелязва различното разбиране в двете системи на „неуспеха” или „усещането за срам” (HOFFMAN 1989: 249); разминаването между „полския романтизъм” и „,американския прагматизъм”, както и между подчертаното търсене на удоволствие в Новия свят и славянската привързаност към носталгията - „най-лиричното чувство, извор на поезия и форма на вярност" (HOFFMAN 1989:115). Затруднението в намирането на точната английска дума за „апаратчик” или обратно - на несъществуващата полска дума „самодостатъчност”/“self-sufficiency” - я карат да се замисли за различните представи за зависимост и независимост в американската индивидуалистична среда и да си спомни “горещината на човешката близост” в Краков, където жилищата са пълни с повече хора, повече разговори и клюки - с една дума „повече живот” (НOFFMAN 1989: 60). Чрез сравняването на думите в двата езика Хофмановата героиня (както и самата писателка) развива все по-силна чувствителност към културните и социални разлики между Изтока и Запада. 
По подобен начин Ева забелязва, че „идентичността” не е категория на ежедневно осмисляне за нейните полски приятели - тя просто е „нещо, което имаш", докато нейните американски приятели внимателно наблюдават превратностите на своята „,identity”, която ту се разпада, ту преминава през несигурност и промяна" (HOFFMAN 1989: 263) и затова дискурсите за идентичността са основна тема на разговор „на английски”. Постепенно дори пространствата започват да се съизмерват чрез съпоставката в/ чрез езика: така Ева назовава Краков „полския Бостон”, а Варшава - „полският Ню Йорк” (HOFFMAN 1989: 44).

Езиковите наблюдения на Хофман показват, че термините и думите не просто пътуват през континентите - те се измерват различно, те пренасят вече прикачените към тях значения от една култура в друга, от едни преживявания към други. Докато расте в Канада и САЩ, Ева сякаш виси във въздуха между полския и английския. С времето родният език атрофира и „се сбръчква от неупотреба" - неговите думи вече не се отнасят до преживяванията на новия континент, до новите предмети, идеи или лица на хората наоколо - така за Ева полският става „езикът на непреводимото минало” (HOFFMAN 1989: 120). В същото време новоусвоените английски думи още не са проникнали в дълбините на психиката и емоциите на младата героиня. Тя е жестоко раздвоена: две различни същества, които говорят на два езика и притежават две различни ценностни и мисловни системи - живееща „между две истории и две лексики “разкъсана на две” (HOFFMAN 1989: 271). В този момент Ева осъзнава, че за да запази разсъдъка си, тя трябва да превърне своето второ (английско) ,аз” в единственото (HOFFMAN 1989: 124) и започва да пише дневника си на английски език, опитвайки се да изгради своята текстуална идентичност на един глас, за да продължи да живее.

Постепенно новоусвоеният език става един от инструментите за навлизането на Ева в чуждата култура и „живота на нов език”. Като студентка в Америка през революционните 60 години Хофман попада във вихъра на социалните движения - исторически момент, когато центробежните сили на протеста оспорват ядрото на центъра. Точно когато тя се опитва да превъзмогне алиенацията си и да намери своето място в мултикултурното американско общество - „да живее в езика и да принадлежи на тази култура” (HOFFMAN 1989: 194), тя осъзнава, че американските ѝ състуденти искат обратното - да разрушат ограниченията на езика и културата. Друго езиково средство, чрез което Хофман се опитва да опосредства своето съществувание и да навлезе в американската култура, е англоезичната литература и особено красивият език на писатели като Хенри Адамс, Т. С. Елиът, Милан Кундера. Тя е особено привлечена от Владимир Набоков - руският майстор на прозата и транлингвалното въображение, който успява да се пре-създаде на английски, като „избягва яростта и малоценността на изгнаничеството” (HOFFMAN 1989: 198). Чрез вълшебството на литературата думите отново стават „красиви неща” (HOFFMAN 1989: 186) за Ева, както в детството й. По ирония на съдбата силното фокусиране върху темата за алиенацията в американската литература също помага на дистанцираната Ева да се пребори със собственото си отчуж- 
дение. Като чужденка, тя се научава да цени своята позиция на наблюдател и критик - също като Теодор Адорно, който преднамерено подхранва собственото си отчуждаване от американското общество и апелира към своите събратябежанци в Америка да приемат състоянието на алиенация и да не търсят асимилация, защото това би означавало да загубят идентичността си. За Хофман обаче подобна позиция на прекалено критично дистанциране е крайна: „Не бих искала да остана във вътрешно изгнаничество до края на живота си, трябва да намеря начин да изгубя алиенацията си без да изгубя себе си" (HOFFMAN 1989: 209).

Тя продьлжава да се бори с новия език - защитава с отличие дисертация в Харвард и става редактор в престижния бастион на словото Ню Йорк Таймс Бук Ривю. Парадоксално, но именно успехът на Ева в битката с новия език я убеждава да промени отношението си към Америка: „Това проклето място сега е мой дом. Сега разбирам кодовете тук. Нащрек, като прилеп, улавям всички сюблимни сигнали, изпратени от думите, погледа, жеста" (HOFFMAN 1989:169-170). Хофман вече не се възприема като отчуждена имигрантка, а като жена със солидна професия, която се идентифицира по-скоро с космополитността на Ню Йорк, която улавя и най-тънките нюанси в разговора, дори и специфичния хумор на Уди Алън. Психоаналитичната терапия също е лингвистична дейност - посещенията на Ева при терапевта започват като лечение с думи, но се превръщат в ритуал на опознаване и обговаряне на собственото ѝ аз или, както сама го определя, умението да „обясни себе си на себе си” или да „преведе себе си на собствения си език” (HOFFMAN 1989: 271).

Най-плодотворният жест на пресьтворяване в/чрез словото и на само-превеждане е обаче написването на собствената ѝ автобиография. Едва когато Ева успява да разкаже целия си живот от самото начало „само на един глас”, като „един човек, в първо лице единствено число” (HOFFMAN 1989: 273), тя престава да бъде болезнено разкъсана. Макар и да живее между два езика и култури, между тях вече не съществува зейнала пропаст. По-скоро това е едно ново състояние на допълване и сдвояване - двойно, а не болезнено раздвоено и шизофренно отделяне. Ева осъзнава както рисковете, така и удоволствията от обитаването на лиминалната зона между различните езици/култури, и се научава да живее в двугласие, дори да мисли различно на двата езика. Така например, когато обмисля дали да се омъжи, вътрешният диалог на размишленията ѝ се осъществява и на двата езика. Отначало въпросът „Да се омъжа ли за него?" прозвучава на английски, последван от утвърдителен отговор, но ехото на същия въпрос - вече на полски - получава окончателния отговор „Не”.

Състоянието на двугласие/ двуезичие може да се разглежда и като акт на превод от полски на английски и обратно: от една страна Ева превежда (приближава) собствените си емоции и преживявания на полски на англо-езичното си обкръжение, а от друга превежда на своите американски приятели полската (си) другост. Преводът прераства от механично движение между думи и структури в акт на разбиране и сближаване, на обяснение и трансформация. Самата тя свиква да живее между езиците назад във времето и после напред, като решава съзнателно: „Трябва да преведа себе си”. Това обаче не е акт на асими- 
лация, а по-скоро на осъзнаване, че истинският превод „извира от актовете на разбиране и съчувствие, че той става на малки натрупвания, изречение след изречение, фраза след фраза" (HOFFMAN 1989: 211). След като разбира, че животът е динамично състояние на превеждане/ прехвърляне/ преминаване през много етапи, Ева приема също така, че съществуват много „езици”, на които той се огласява: езикът на чувствата, на любовта, на психотерапията, на музиката - най-съвършеният и универсален език. Романът завършва с примирие между света и думите, между образите и матрицата на езика: в една градина в Кеймбридж Хофман съзерцава красивите цветя и техните трудни за запомняне имена изведнъж изникват на английски (азалии, зюмбюли, делфиниуми...). Тя най-после осъзнава, че английският език и полският „култивират различни градини” и приема лиминалността си в/ между езиците.

Движението между езиците в романа Изгубена в превода функционира не само като сложна метафора на приемането на културните различия, но и като инструмент за анализиране на почти четиридесет години от живота на една жена-писателка. „Като всички” - заключава Хофман - „аз съм сборьт на моите езици - езикът на моето семейство и детство, на образованието и приятелството, на любовта и на променящия се свят” (HOFFMAN 1989: 273). Животьт в превод я научава да усеща „относителността на културните значения с кожата си” и да не възприема значенията като окончателни... Тя приема двойната си и дори множествената си същност, че е изградена/ написана на различни езици, че в някаква степен е ,ръкопис” (HOFFMAN 1989: 275). Още по-точно би било да определим идентичността на нейната преведена същност като палимпсест: фигура с много пластове, с много акустични следи от различни езици от миналото и настоящето.

Романите на Александър Хемон също внушават, че езиците не са напълно съизмерими и че всеки език смила и запечатва преживяното по свой уникален начин - сякаш един единствен език не стига да се преживее вселената от мигове и места в един човешки живот. Макар и с различна съдба, статут и стил на писане, Хемон също пресъздава себе си на чужд език в САЩ и отново акцентира на връзката език-култура. Младият мъж напуска Босна за кратко посещение в Америка през 1992 година, но точно тогава избухва войната в бивша Югославия и той остава „увиснал” в Чикаго като случаен турист, номад, а покъсно и емигрант. Докато следи по телевизията войната в родината си, той осъзнава, че вече не може да пише на босненски език. Хемон обяснява решението си да се изразява на английски като естествена реакция: „Не можех да пиша на родния си език. Бях откъснат от войната, от преживяванията, които определяха света ми. Когато ме помолиха да напиша няколко статии за списанието Дани в Сараево, на което бях сътрудничил по-рано, опитах да продиктувам няколко откъса по сателитния телефон, но ситуацията беше повече от абсурдна. Всичко изглеждаше безсмислено."5 Макар и да не се появява директно на повърхността в романа Човекът от никъде: фантазиите на Пронек, войната наднича иззад всички събития и преживявания, описвани от боснен-

\footnotetext{
5 Интервю с Александър Хемон, виж http://www.aleksandarhemon.com/
} 
ския автор - често под формата на случайни заглавия от вестниците: „Защитата пропада в Горажде”, „Кланетата продължават,” „Хиляди избити в Сребреница” .... (HEMON 2002: 145, 155).

Първият транслигвален роман на Хемон е полу-автобиографичен разказ за един младеж от Сараево - Джозеф Пронек, който не принадлежи никъде. Самият наратив включва седем различни разказа, които се движат между Европа и Америка - от Сараево към Чикаго, от Чикаго към Киев, както и във времето на целия ХX век. На пръв поглед описваните случки и събития изглеждат несвързани - обединени единствено от главния герой Джозеф Пронек и съответно неговите роднини от Босна и Украйна, както приятели и случайни познати от двете страни на Атлантическия океан. Както подсказва заглавието на постмодерния роман, действието се разгръща под формата на фантазия или по-скоро на кошмар. Транс-езиковият наратив започва през 1994 година в Чикаго с признанието на героя „Ако това наистина е сън, предпочитам да се бях озовал другаде” и завършва през 2000-та година в Шанхай - в леглото на хотелска стая, точно преди да го нападне поредния кошмар: „Нишо не мога да сторя, за да го спра. По-добре да ставам" (HEMON 2002: 242). По този начин рамката на съня/ кошмара от самото начало размива границите между реално и нереално, като подтиква читателите да си представят какво би станало, когато героят се събуди и прогледне.

Наративната ситуация се усложнява допълнително от факта, че отделните истории са разказани от няколко разказвача - в повечето случаи в първо лице единствено число от самия Пронек, понякога от безименен сънародник босненец, а в други случаи от Виктор Плавчик - американец от украински произход, с който Пронек споделя една и съща стая по време на лятно училище в Украйна. Това многогласие се усилва от най-различни други гласове, които изникват от различни места и моменти от миналото и настоящето. Често използвана форма са писмата или съобщенията, които достигат до него от разпадналата се родина. Например, в едно писмо от Босна негов съученик описва в детайли как бившата приятелка на Пронек е загубила крайниците си в бомбардировка, докато чака на опашка за хляб на пазара. В друго писмо - с дата декември 1995 година, най-добрият му приятел от Сараево, Мирца го информира, че войната е свършила: „Скъпи, Джозеф!...Не знам какво мога да кажа. Войната е всичко за мен. Искам да говоря за нещо друго, но не съм гледал никакви филми, никаква музика, никакви книги... Извинявай, много говоря. Ние в Сараево няма с кой да говорим, никой не иска слуша тези истории.... Затова малко съм луд. Пиши на мен. Твой, Мирца. П.С. Честита Нова година" (HEMON 2002: 132-34). Накъсаните изречения, написани на неправилен английски с двойни отрицания, сбъркани предлози и времена всъщност са превод на самия Пронек за самия него - грешките внушават невъзможността да се назоват или изкажат „правилно” човешката болка и отчаяние. Както и при Хофман, чуждият език отново се спъва в абстрактните понятия „война”, „болка” и „страх”, които имат много конкретни измерения на босненски, но не могат да бъдат назовани точно на английски заради накъсаната връзка с реалността и вътрешните преживявания на оцелелия приятел от Босна. 
За разлика от Хофман, която запазва собственото си име в „Изгубена в превода", романът на Хемон е написан през дистанцираната гледна точка на неговото алтер-его или двойник Джозеф Пронек. Въпреки това и в неговия случай преживяванията отвъд родината и майчиния език водят до болезнено раздвояване на личността. Изгнаник в Чикаго, без пукната пара и приятели, Пронек опитва всякаква работа - от учител по английски като втори език (където разказвачът се разпознава сред учениците) до помощник в детективска агенция и дори агитатор за Грийнпийс. Животьт на босненеца в Чикаго е доста мрачен: той едва оцелява с минимални надници, самотен, в празен апартамент, населен с хлебарки. За разлика от Хофман, просмукана от тихо отчаяние, той е изпълнен с гняв през цялото време: човек без място и корени, който не се идентифицира нито с родината си, нито със страната, където случайно намира убежище. Пронек се самоопределя като „човек от никъде” - фраза от любима песен на Бийтълс, която на младини е изпълнявал в Сараево с младежката група „Бубе” (директен превод на Бийтълс). Музиката и особено песните на английската поп-група функционират като подтекст на носталгията по безгрижното детство и юношество в някогашната „цяла” Югославия. Рефренът на песента „Yesterday” - „Вчера всички мои беди изглеждаха толкова далеч” (HEMON 2002: 54) - често озвучава мислите на героя, препраща към весели спомени от миналото и служи като вододел между миналото и настоящето. От дистанцията на безвремието и безсъбитийността в Америка дори комунизмът в Титова Югославия изглежда по-скоро смешен, отколкото ужасен: Пронек си спомня със смях епическите битки да се сдобие с китара и да промени лицето на рокендрола в Югославия, абсурдното си битие в казармата, играта на стьклени топчета, първите сексуални подвизи, въставането срещу родителите, пионерските лагери с китарите и бодрото припяване на „Жълтата подводница”. Преди войната „големите” събития в живота на героя са рок концертите, убийството на Джон Ленън, отложеният концерт на младежката им рок група на 4 май 1989 година заради смъртта на Тито и „неговата егоистична тленност” (HEMON 2002: 44). За Пронек Сараево от 80-те години на XX век е „красиво място” на безгрижен и щастлив живот, за което си спомня с носталгия, или онова чувство, което може да изкаже само на майчиния език „севда” - приятна душевна болка” (HEMON 2002: 49). Подобно на полската дума „teşknota”, която изпълва съзнанието на Хофман и нейната героиня, Хемон изпитва същата странна смесица от болка и радост, дори още по-странна, защото става въпрос за носталгия по родината, отхвърлена от самия него.

Елементи от по-ранните му преживявания винаги се изпречват на пътя на мисьлта и емоциите му в настоящото: радостните емоции от югославското детство прозират дори през травмата на войната, която накъсва живота му на две - както във времето (преди и сега), така и в пространството (Сараево и Чикаго). Усещането за носталгия по родното се усилва от разочарованията на Пронек в Америка: тя изобщо не отговаря на утопичната имигрантска представа за земята на свободата. Разказите му за американската действителност не съдържат нито една хвалебствена дума. Пронек остава дистанциран от новата си среда, неспособен да се приспособи : сякаш живее с Америка, а не в 
Америка. Покрай работата му в Грийнпийс, където събира дарения за спасяване на природата, делфините, горите и т.н., Пронек има възможност да надникне в домовете и живота на много американци от предградията на Чикаго, които му се струват напълно погьлнати от работата си и самотни. Именно чрез взирането в другите Пронек осъзнава собствената си разпокъсана идентичност едновременно на беглец, имигрант и самотник. Босна не съществува на географската карта на американците: те не са я чували, не знаят къде се намира, бъркат я с Чехословакия, с Пном Пен дори (HEMON 2002: 149). Поясненията на Пронек за странното му положение без родина и език поради разпадането на Югославия не помагат. Например, когато го изпращат да даде призовка на някакъв сърбин, защото говори същия „маймунски език” (HEMON 2002: 159), той усеща пълната си отчужденост от славянските си корени, както и от себе си. Националистьт-сьрбин го посреща с пушка и кафе, като първо настоява да научи дали Пронек е сърбин или мюсюлманин. Пронек не знае какво да отговори, просто измърморва: „Аз сьм сложен. Може да се каже, че съм босненец” (HEMON 2002: 146).

С времето кризата на идентичността на младия босненец се задълбочава: той е все по-отчаян, „съсипан човек, без бивша или настояща страна”. Пронек се отчуждава от самия себе си: на семейство в Еванстън се представя като „Мирца от Босна”, на една колежанка - като Сергей Катастрофенико от Украйна, на стареца в парка - като Жука Смрдипрдиушкас от Естония, за двойка старци от Румъния, които не говорят английски, той „минава” за Джон от Ливърпул, за гневния строителен работник той е „Никой”, за католическия свещеник е Филип от Люксембург, за велосипедистите на паркинга е Джозеф от Шнитцланд (родината на шницела), за жената от Хайд Парк, която с разочарование го посреща на вратата с думите „Мислех, че е някой друг”, той се назовава „Някой друг” (HEMON 2002: 179-180). Само в няколко поредни изречения Пронек сменя серия от идентичности със странни имена, националности, професии - двойни и множествени гласове, които не звучат като диалог, а поскоро като какофония.

Странните самоидентификации на Пронек не са игра на фантазиране; те сигнализират не само неспособност да назовеш нещата точно или да ги артикулираш съзнателно (както у Хофман), а пълно накъсване на субекта на изказванията. Пронек непрестанно е „някой друг”- както в пространството на сегашността, така и във времето. Той сякаш живее нечий друг живот, като непрестанно си спомня миналото, когато е бил наистина „друг”- отново през рефрена на песента на Бийтълс „Вчера” - „Изведнъж, не съм и половината от онова, което бях, над мен се е спуснала сянка...О, вчера" (HEMON 2002: 196). Транс-езиковото лутане между босненския и английския език показва невъзможността му да намери отправна система; той е „човек от никъде”, който гради и живее в светове от думи без съдържание. Справките в речника не помагат на Пронек да намери точните значения и нюанси на думите - например проверката на английската дума „смърт” не му помага да разбере какво става в родината му. Пронек търси скрит смисъл във всичко наоколо, дори и в имената на хората, които среща: така превежда името „Роман” със съответния белетри- 
стичен жанр, „Брдианин” - с „Планинец”, „Зора” - с „ранно утро”. Подобно на полските следи у Ева Хофман, английските му изречения са изпълнени със сърбо-хърватски и босненски думи: „будала”, „православни брат”, „кафу”. Понякога английските думи го затрудняват и той се чувства неловко от детинските си граматични грешки, от погрешните предлози и времена, от неправилното членуване или пък от струпването на прекалено много членове. Езиковите несъответствия внушават изместването му от родния език и култура - дори времената придобиват иронични нотки. Например, докато имигрантите в часа по английски език правят упражнения за употребата на минало и сегашно перфектно време, Пронек прониква отвъд граматичните структури на повтаряните фрази:

„Никога не съм чел Моби Дик.

Никога не съм виждал Гранд каньона.

Никога не съм бил в Ню Йорк.

Никога не съм бил богат" (HEMON 2002: 13).

Повторението на отрицателните изречения изгражда една особена граматика на отсъствието - на лишеността на имигрантите от есенциалния американски опит, свързан с литературния канон, ценностите или забележителностите на Америка, на тяхната неамериканскост и непринадлежност. Дистанцията на героя от всичко го превръща в идеален наблюдател не само на американския живот, но и на самия себе си. В същия този час по английски език в Чикагското училище Пронек „вижда” себе си сред имигрантите:

„Пронек погледна право към мен. Не знаех дали може да ме познае - доста се

бях променил, бях прекарал продължителна и съкрушителна болест - той обаче продължаваше да се взира в мен. Избегнах погледа му, а сърцето ми тупкаше. Как се бе оказал тук? Дали той бе в Сараево под обсадата? Или той бе обсадил града? Каква беше неговата история? Какъв беше животьт му?” (HEMON 2002: 25).

Неслучайно часовете по усвояване на новия език се оказват ключов момент за завръщане към родния славянски език, чрез който босненецът в Америка се опитва да пречупи и изрази собствените си преживявания, за да влезе в диалог с основния език на обкръжението си. Но както показва вътрешният монолог по-горе, Пронек остава съдвоен и разделен между двете езикови съзнания, като зад всяка дума наднича някакъв призрачен индивид. Транс-езиковото въображение на Пронек, което се лута между два континента, му помага да осъзнае, че не иска да бъде в Америка, но и че „няма определено място, където иска да бъде” (НЕMON 2002: 219). Подобно на полската героиня Ева, накрая той успява да се примири със себе си и да приеме своята неустановеност и другост.

Анализираните примери от романите на Хофман и Хемон показват в каква степен сме изградени от езика, мястото, както и историята на своето битие. Макар и да започват живот в нова страна и на нов език, трансформацията на техните герои на английски не е пълна и лесна. В произведенията и на двамата автори ключовата дума е тьга по родното и тя остава да звучи на родния език (съответно "teşknota" и "sevdah"). Транс-езиковото въображение се оказва един от факторите техните герои да не претопят своята другост, както и да развият аналично и критично съзнание. Външната перспектива на героите поражда технологии на отчуждаването - дистанция едновременно от двете култури, 
но и от себе си. Като цяло, в двата романа се срещат три основни модела на въобразяване на другостта: чужденец в собствената си страна, другият като чужденец и представата за себе си като чужд. Първият и вторият тип присъстват съвсем бегло, докато третият модел на другостта - определено най-интересен и саморефлективен - преобладава и в двете произведения. Героите на Хофман и Хемон (както и техните автори) наблюдават и коментират своето собствено отчуждаване от себе си при откъсването им от родния език и култура: от една страна болезненото разделение на Ева (маркирано с промяната в славянското ѝ име), а от друга страна, силно сардоничната позиция на Пронек (изразена в собствената му фраза „Аз съм някой друг”).

В съвременната теория маргиналността, другостта и дистанцията в изкуството и живота се ценят високо. Още руските формалисти изтькват задачата на литературата да остранности и очудни езика, за да подсили възприемането на познатото като непознато - така нареченото от Виктор Шкловски „остранение” или ,дефамилиризация”. Макар и от друга позиция (на пост-колониалната теория), Пол Гилрой също подчертава способността на индивида да „култивира известна степен на отчуждаване от собствената култура и история" (GILROY 2006: 75) като необходимо условие за появата на нов вид космополитно мислене - така наречения „народен космополитизъм”, който се свързва с движението не на елитите и привилегированите класи, а на множеството хора и групи от различни диаспори. 6 Хемон и Хофман развиват именно такава ценна чувствителност - независимо дали ще я определим с термина на дюБойс „двойно-съзнание” или педагогиката на отчуждаването и само-отчуждаването на Кръстева, която ни позволява „да интерпретираме” и да „си представяме” нещата по различен начин.

Транс-езиковото въображение на Хофман и Хемон произвежда различни ефекти на отчуждаване. На първо място, то лансира една естетика на отчуждаването: изразяването на чужд език прави невъзможно думите и реалността да се вземат за даденост, забавя мисленето, прави формите по-трудни, де-автомизира мисленето и писането, подобно на ефекта на „остранението” на Шкловски. На второ място, то действа като вид културно посредничество: транслингвалните автори посредничат между двете културни традиции, като превеждат едната на езика на другата и обратно. И на трето място, транс-езиковото литературно писане води до само-отчуждаване на твореца, до неговото пре-сътворяване в някой друг, като в процеса на мултициплиране на езиците се създава и по-всеобхватна и многопластова субектност. До голяма степен трансезиковото съществуване е форма и на номадство, но не просто като физическо преместване в пространството, а като флуидна и променлива субектност. В книгата си Номадски субекти: превъплъщзаване и сексуални различия в съвременната феминистка теория Роузи Брайдоти лансира идеята за номадската субектност, базирана на модела на номада. Този положителен модел на субекта

\footnotetext{
6 Самата Хофман сподели в интервю през 2011 г.,че вече не се възприема като изгнаник, а като „номадска личност, която в един момент може да се промени в нещо космополитно - където космополитното извира не от малко на брой привилегировани и значими центрове, а отвсякъде” (PHOENIX and SLAVOVA 2011: 345).
} 
в движение, който живее между езици, култури, традиции, тя нарича „критично съзнание, което се съпротивлява на установените начини на мислене и поведение” (BRAIDOTTI 1994: 5). Брайдоти разграничава три основни фигури на преселеност: изгнание, миграция и номадство. За разлика от изгнаника, които има „остро усещане за чуждост, застинал в миналото, с изгубени хоризонти и живот в бъдеще перфектно време”, или от емигранта, който следва „ясна дестинация, но е с блокирани хоризонти и живее в сегашно перфектно време”, номадът се характеризира с отказ от идеята за установеност или фиксираност и живее в „несвършено време” (BRAIDOTTI 1994: 24-25).

От тази гледна точка транс-езиковите герои на Хофман или Хемон, както и техните създатели, би трябвало да се разглеждат не като изгнаници или емигранти, а като номади, които в живота между родния и чуждия език развиват особено космополитно съзнание отвъд определен език, нация или култура, както и способност да мислят и си представят света по различен от установения начин.

\section{Библиография}

BRAIDOTTI, R. (1994): Nomadic Subjects: Embodiment and Sexual Difference in Contemporary Feminist Theory, Columbia University Press, New York.

GILROY, P. (2006): After Empire: Melancholia or Convivial Culture?, Routledge University Press, New York.

HOFFMAN, E. (1989): Lost in Translation: A Life in a New Language, Penguin Books, New York.

HEMON, A. (2002): Nowehere Man, Random House, New York.

KELLMAN, S. (2000): The Translingual Imagination, University of Nebraska Press, Lincoln and London.

KRISTEVA, J. (1991): Strangers to Ourselves, Trans. Leon S. Roudiez, University of Columbia Press, New York.

PHOENIX, A. SLAVOVA, K. (eds) (2011): "Living in Translation: A Conversation with Eva Hoffman", European Journal of Women's Studies, vol.18, n.4. 